\title{
鋼繊維補強 $\mathrm{AE}$ コンクリートの配合に \\ 関する若干の実験
}

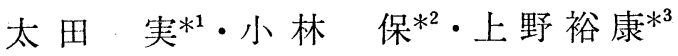

\begin{abstract}
概 要ここの報告は, 空気量 $6 \%$ 程度混入した鋼繊維補強 $\mathrm{AE}$ コンクリートの配合に関する実験について述べたもの である。すなわち, 細骨材率, 鋼阷維混入率, 単位水量などがスランプ, 空気量, 強度などに及ぼす影響を検討した結果, 鋼繊維補強 $\mathrm{AE}$ コンクリートに所要の空気量を混入するのに必要な $\mathrm{AE}$ 剂量, 指定された鋼繊維混入率のコンクリートを 作るのに適当な細骨材率，所要のスランプを得るに必要な単位水量などの目安を得たものである。

キーワード：鋼繊維補強コンクリート，配合， $\mathrm{AE}$ コンクリート
\end{abstract}

\section{1.はじめに}

鋼繊維補強 コンクリートは，コンクリートの脆性改 善，凍結融解作用に対する耐久性の向上などの効果が期 待されており，コンクリート舗装，道路橋床版などへの 適用も試みられているが，鋼㵶維補強コンクリートの配 合設計に関する参考資料が少ないので，そのつどかなり の試し練りを行っているのが実情である。この報告は， そのような場合の配合設計の参考に供することを目的と して，AE 剂を用いた鋼繊維補強コンクリートの配合試 験の結果を述べたものである。実験は，予備実験 2 系列 と主実験 1 系列に分けられる。主実験において空気系量 を $6 \%$ と設定したので所要の $\mathrm{AE}$ 鼡量を推定するため に予備実験を実施した。

\section{2. 使用材料及び測定}

\section{（1）使用材料}

使用したセメントは，日本セメント社の普通ポルトラ ンドセメント（比重 3.16）で, 細骨材は川砂, 粗骨材

\section{表一1 骨材の性質}

\begin{tabular}{|c|c|c|c|c|}
\hline & 比重 & $\begin{array}{c}\text { 吸水率 } \\
(\%)\end{array}$ & 粗 粒率 & 考 \\
\hline 細 骨 材 & 2.61 & 2.26 & 3.15 & 富士川産川砂 \\
\hline 粗 骨材 & 2.69 & 0.90 & 6.56 & 佐野市産砕石 \\
\hline
\end{tabular}

*1 正会員 建設省土木研究所 コンクリート研究室長

*2 正会員 建設省土木研究所 コンクリート研究室 研究員

$* 3$ 正会員 大成道路 (株) 技術研究所 基礎研究室長
は砕石である。これら骨材の性質を 表一1 に示す。 $\mathrm{AE}$ 剤は, 山宗化学社のビンソールを用いた。鋼纎維は, 冷 延薄板をせん断し, 寸法 $0.5 \times 0.5 \times 30 \mathrm{~mm}$ としたサン ゴ社製のもので，比重は 7.85 である。

\section{(2)，練りまぜ及び測定}

コンクリートの練りまぜは, 容量 $100 l$ の強制練りミ キサを用い， 1 バッチの量を $40 l$ として鋼繊維以外の 全材料をミキサに投入後 1 分間練りまぜ, その後鋼繊維 を手でほぐしながら投入し（鋼䋊維の投入に要した時間 は 1 分間)，その後更に 30 秒間練りまぜた。なお基準コ ンクリート注1)のように 鋼繊維を含まないコンクリート の練りまぜ時間は，全材料投入後 1 分間とした。

ミキサから排出したコンクリートは，1 往復の切り返 しを行った後, コンクリート温度, スランプ及び空気量 を測定した。コンクリート温度注2)の測定にはアルコー ル棒状温度計を用い，また，スランプ試験は JIS A 1101, 空気量試験は JIS A 1128 の空気室圧力方法によ った。後述の主実験における鋼繊維補強 $\mathrm{AE}$ コンクリ ートについては, 更に圧縮強度試験用供試体 $(\phi 15 \times 30$ $\mathrm{cm})$ 及び曲げ試験用供試体 $(15 \times 15 \times 53 \mathrm{~cm})$ を 1 バッ チあたりおのおの 2 個ずつ採取した。供試体の締固め は，圧縮用が 2 層，曲げ用は 1 層詰めとし，各層ごとに テーブルバイブレター（回転数 $3000 \mathrm{rpm}$, 振幅 0.6 $\mathrm{mm}$ ）を用いて充分に締め固めた。養生は標準養生とし， 材令 28 日において，圧縮は JIS A 1108，曲げは JIS A 1106 に従って強度試験を行った。

注 1) 鋼繊維補強 $\mathrm{AE}$ コンクリートの配合から 鋼纎維のみ を取り除いた配合のコンクリート

注 2）実験中のコンクリート温度は $23 \sim 24^{\circ} \mathrm{C}$ である。 


\section{3．空気量に関する予備実験の結果}

後述する主実験において, 目標空気量を $6 \pm 1 \%$ と設 定したので,これに必要な単位 $\mathrm{AE}$ 剂量の目安を得る ための予備実験を行った。

まず初めに，空気量に及ぼすスランプの影響を調べる ため, 表一2 に示すように, 水セメント比及び細骨材率 を一定とし, 単位水量のみを変化させることによってス ランプを変化させ, スランプと空気量との関係を検討し

表一2 実験要因（空気量に及ぼすスランプの 影響を調べる予備実験）

\begin{tabular}{|c|c|c|}
\hline & 要 因 & 要因の水準 \\
\hline 変 & 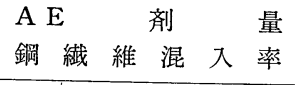 & $\begin{array}{l}C \times 0 \%, C \times 0.02 \% \\
0 \%, 1.5 \%\end{array}$ \\
\hline \multirow{2}{*}{ 動 } & 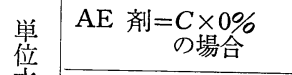 & $189 \mathrm{~kg}, 230 \mathrm{~kg}$ \\
\hline & $\mathrm{AE}$ 剂 $=\underset{\text { の場合 }}{C \times 0.02 \%}$ & $183 \mathrm{~kg}, 201 \mathrm{~kg}, 223 \mathrm{~kg}$ \\
\hline 一 & $\begin{array}{l}\text { 水七メント 比 } \\
\text { 細骨 材 率 } \\
\text { 粗骨材の最大寸法 }\end{array}$ & $\begin{array}{l}50 \% \\
60 \% \\
20 \mathrm{~mm}\end{array}$ \\
\hline
\end{tabular}

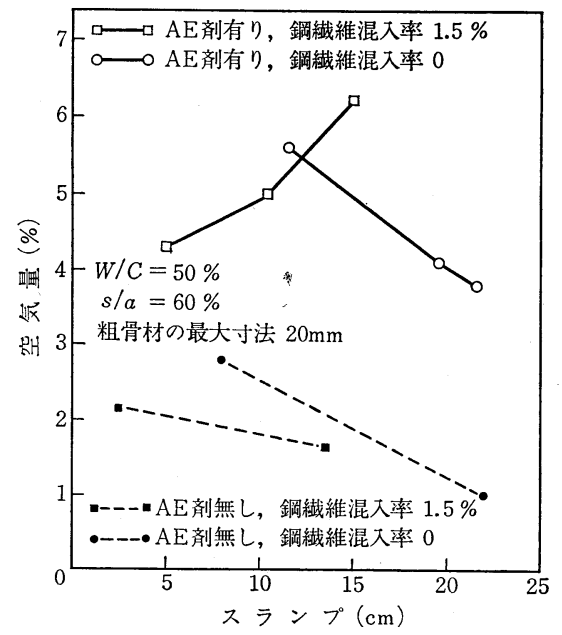

図一1空気量に及ぼすスランプの影響
た。 $\mathrm{AE}$ 剂の使用量はセメント量に対する重量比で表す こととし，0及び $0.02 \%$ とした。鋼繊維混入率は 1.5 $\%$ とし，鋼繊維混入率 0 のものを基準コンクリートと した。実験の結果は図一1に示すと扔りで， $\mathrm{AE}$ 剂を用 いないコンクリートではスランプが大きくなるとエント ラップトエアーがわずかに減少する傾向が認められ，ま た，同一スランプでは鋼纎維の混入によってエントラッ プトエアーが減少する傾向が認められる。セメント量に 対する $\mathrm{AE}$ 剤の重量比を一定にした $\mathrm{AE}$ コンクリート の場合, $\mathrm{AE}$ 剂を用いないコンクリートと同様に, スラ ンプが大きくなると空気量が減少する傾向にあるが，鋼 纎維を混入したコンクリートでは, 逆にスランプが大き くなると空気量が増加する傾向が認められる。

つぎに、スランプに及ぼす空気量の影響を調べる実験 を行った。ここでは, 水セメント比を $50 \%$, 細骨材率 を $60 \%$, 単位水量を $207 \mathrm{~kg}$, 鋼繊維混入率を $1.5 \%$ とそれぞれ一定とし, 単位 $\mathrm{AE}$ 剤量のみを変えること によって空気量を変化させ, 空気量とスランプ量々の関 係を検討した。実験の結果は図一2のとおりでこれに よれば, 鋼繊維混入率が $1.5 \%$ の場合, 空気量 1 \% の変 化に対応するスランプの変化はおよそ $0.7 \mathrm{~cm}$ で饬る。 鋼繊維を混入しない $\mathrm{AE}$ コンクリートでは, 空気量 $1 \%$ の変化に対応するスランプの変化は,一般におよそ: $2 \mathrm{~cm}$

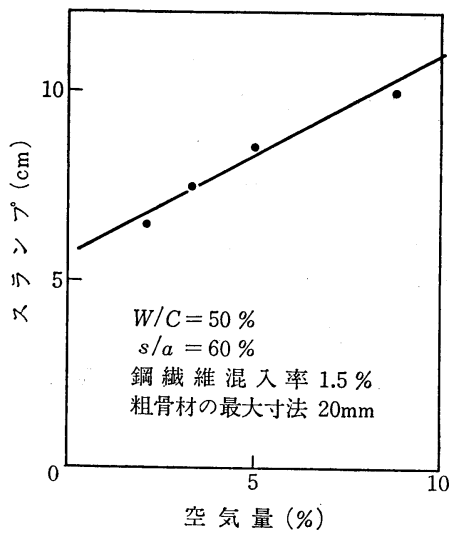

図一2 スランプに及ぼす空気量の影響

Some Experiments on Mix Proportion of Fiber Reinfoced Air Entrained Concrete By Minoru Ohta, Tamotsu Kobayashi and Hiroyasu Ueno

Concrete Journal Vol. 16, No. 10, Oct. 1978, pp. 21 26

Synopsis This report describes the results of experiments on the mix proportion of fiber reinforced concrete with about 6 percent air content. Discussing about influences of sand percentage, fiber content and water content on air content, slump and strength of concrete, the approximate required values of air entraining agent to get the required air content, and of sand ratio to get preferable concrete with designated fiber content, and of watər content to get the required slump are found out.

Keywords : fiber reinforced concrete, mix proportion, air entrained concrete 
とされている11。従って, 鋼繊維補強 $\mathrm{AE}$ コンクリート では鋼䋊維を混入しないコンクリートに比べて, 空気量 $1 \%$ の変化に対応寸るスランプの変化は小さくなるもの と考えられる。

この予備実験の結果を参考にして, 空気量 $6 \%$ とする のに必要な単位 $\mathrm{AE}$ 㓮量を推定し, 試し練りによって 修正し，その結果にもとづいて主実験を行った。

\section{4. 主実験の実験要因及び実験結果}

\section{(1) 実験要因}

実験で採り上げた要因を 表一3に示す。变動要因は, 細骨材率, 鋼緎維混入率及び単位水量の 3 種類とした。 既往の研究 2 によれば，鋼繊維補強コンクリートの配合 における細骨材率の值は, 鋼繊維を混入しないコンクリ 一トの配合とは比較にならないほど重要な意味をもつこ とが認められている。そこで, 細骨材率を $20 \%$ から $100 \%$ まで変化させてその影響を検討した。鋼䋊維混入 率については, 既往の研究 ${ }^{3)}$ にれば練りまぜ可能な最 大の混入率が存在することが認められ，その值は使用す る鋼繊維の形状などの要因によって変化するが，おおむ ね $2 \%$ 程度とされている。そこで, 鋼瀻維混入率を 1.0 $\%, 1.5 \%, 2.0 \%$ と変化させた。単位水量については, とくに水準を定めず，他の要因の水準を同一としたコン クリートのスランプが，拉よそ $6 \sim 14 \mathrm{~cm}$ の範囲に適当 に散らばるように 3 個の值を選んだ。実験の結果スラン プが適当に散らばらなかった場合には更に単位水量の水 準を 1 個追加した。実験要因のうち, 水セメント比, 空 気量及び粗骨材の最大寸法は一定とした。空気量は許容 誤差を土 $1 \%$ に設定し, 単位 $\mathrm{AE}$ 剂量を調節してこの 範囲に納まるようにした。表一3 に揭げる要因の組合せ により定まる配合を1バッチずつ練りまぜて所定の測定 を行ったほかに, それらの基準コンクリートも 1 バッチ ずつ練りまぜ, 空気量及びスランプを測定した。基準コ ンクリートの空気量については, $6 \pm 1 \%$ の範囲に納ま っているとは限らない。なお, 鋼瀻維は外割計算とした ので, 鋼繊維補強 $\mathrm{AE}$ コンクリートの示方配合の練り 上り容積は $1 \mathrm{~m}^{3}$ より若干大きめとなっている。

\section{表-3 実験要因（主実験）}

\begin{tabular}{|c|c|c|}
\hline \multicolumn{2}{|c|}{ 要 } & 要因の水準（または水準数） \\
\hline 変 & $\begin{array}{l}\text { 細 骨 材 率 } \\
\text { 鋼 繊 維 混入率 }\end{array}$ & $\begin{array}{l}20 \%, 40 \%, 60 \%, 80 \%, 100 \% \\
1.0 \%, 1.5 \%, 2.0 \%\end{array}$ \\
\hline 動 & 単 位 水 量 & 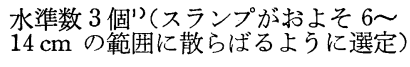 \\
\hline 定 & $\begin{array}{l}\text { 水セメント比 } \\
\text { 空 気 量 }\end{array}$ & $\begin{array}{l}50 \% \\
6 \pm 1 \% \%^{2)} \text { (空気量がこの範囲に納ま } \\
\text { るように剂量を位 } \mathrm{AE} \text { 定) } \\
20 \mathrm{~mm}\end{array}$ \\
\hline & & 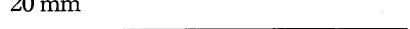 \\
\hline
\end{tabular}

（2）鋼繊維の混入による空気量及びスランプの変化 空気量及びスランプに関する実験結果を, 鋼繊維補強 $\mathrm{AE}$ コンクリートとその基準コンクリートとを対比して 検討した。図一3 は, 鋼繊維補強 $\mathrm{AE}$ コンクリートの スランプと, 鋼纎維補強 $\mathrm{AE}$ コンクリートと基準コン クリートの空気量の差との関係を示したものである。図 -1 に示す予備実験の結果より, スランプが大きい範囲 では鋼繊維の混入により空気量が増加し，スランプが小 さい範囲では鋼繊維の混入により空気量が減少すると予 想されたが，そのような傾向は，図一3でも細骨材率が 極端に小さい場合を除いて認められる。細骨材率が 40〜 $60 \%$ の範囲では鋼繊維補強 $\mathrm{AE}$ コンクリートのスラン プと鋼繊維の混入による空気量の増加との関係は, おお
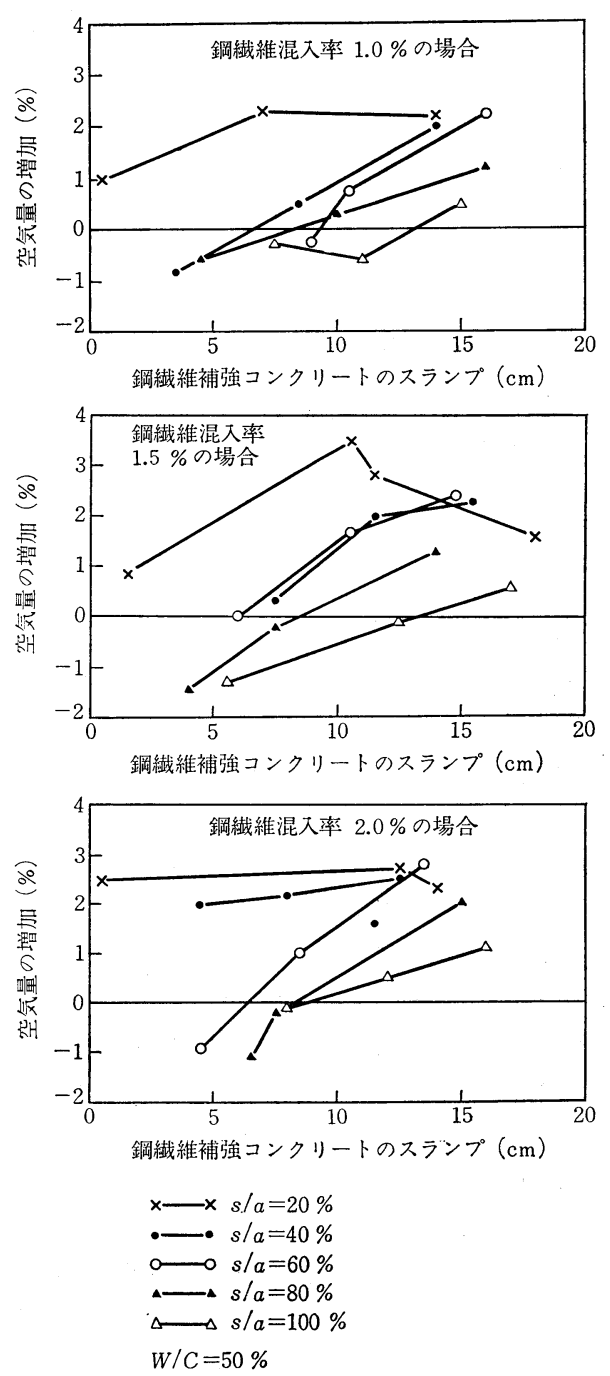

鋼繊維補強コンクリートの空気量 $6 \pm 1 \%$ 粗骨材の最大寸法 $20 \mathrm{~mm}$ (砕石)

図一3鋼縺維の混入による空気量の変化 

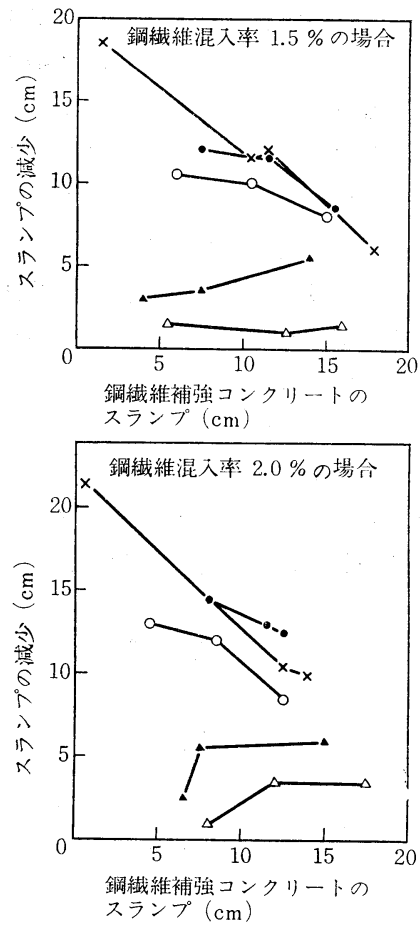

図-4 鋼織維の混入によるスランプの変化

むね直線的であると認められる。このような傾向を考慮 すると, 鋼繊維を混入しない AE コンクリートに関する 既往の経験を鋼繊維補強 $\mathrm{AE}$ コンクリートの単位 $\mathrm{AE}$ 剤量の決定に生かすことができる。すなわち, 予想され る空気量の変化を見込んで基準コンクリートの配合設計 を行らわけである。

図一4 は, 鋼緎維補強 $\mathrm{AE}$ コンクリートのスランプ と基準コンクリートと 鋼繊維補強 $\mathrm{AE}$ コンクリートの スランプとの差との関係を示したもので, これは, 基準 コンクリートに鋼繊維を混入した場合のスランプ減少量 を示すものである。この図が，もし明確な傾向を示すな らば, 所定のスランプの 鋼繊維補強 $\mathrm{AE}$ コンクリート を得るために, 鋼繊維混入によるスランプの減少分を加 えた基準コンクリートを配合設計すればよいことにな り，鋼㵶維を混入しない $\mathrm{AE}$ コンクリートに関する既 往の経験を生かすことができる。AE 剂を混入しない鋼 繊維補強コンクリートについては, この可能性を示した 研究4) がある。しかし, 鋼繊維補強 $\mathrm{AE} コ$ コクリート については，この考え方は適用できないようである。す なわち, 細骨材率の小さい配合では, 鋼繊維補強 $\mathrm{AE}$ ב ンクリートのスランプが大きくなると鋼㵶維の混入によ るスランプの減少が小さくなる傾向が認められるが, 細 骨材率の大きな配合ではこのような 傾向は認められな い。また，一般には鋼繊維の混大によってスランプが減 少すると考えられるが, 細骨材率がかなり大きくかつ鋼
繊維混入率の小さい配合では, 鋼繊維の浔入によ ってスランプの増加している例もあり, 明確な傾 向は見出せなかった。これは，鋼繊維の混入によ って空気量が変化し，スランプを不規則に変化さ せることが原因となっていると推測されう。

（3）スランプー定のときの細骨材率し単位水 量との関係

今回の実験ではスランプを一定としななったの で，スランプを一定としたときの細骨材哑と単位 水量との関係を直接求めることはできないが，つ ぎのような手順によって間接的に求めた。まず, 実験結果から単位水量とスランプとの関喺を求め ると，図一5 のようになる。実験結果に比多少の ばらつきはあるが，いずれも図中に描いだような ゆるい曲線を想定することができる。これより， それぞれの細骨材率及び鋼纎維混入率に芯じた曲 線を用いることにより， スランプ $8 \mathrm{~cm}$ 㱼び 12 $\mathrm{cm}$ に対応する単位水量を求め, 図一6を渵いた。 例えば，図一6のA点は, 図一5 中の曲絙! (1) よ りスランプ $8 \mathrm{~cm}$ に対応する単位水量 $19: 2 \mathrm{~kg} / \mathrm{m}^{3}$ を読み取ってプロットしたものである。殴一6よ り，鋼纎維補強 $\mathrm{AE}$ コンクリートの配合·設計に 関する若干の情報が得られる。すなわち, コンクリート の単位水量はできるだけ少なくすることが 望ましいの で, 図一6 の曲線から単位水量が最小となる細骨材率を 選び，これを配合設計に用いるのが良いと考えられる。
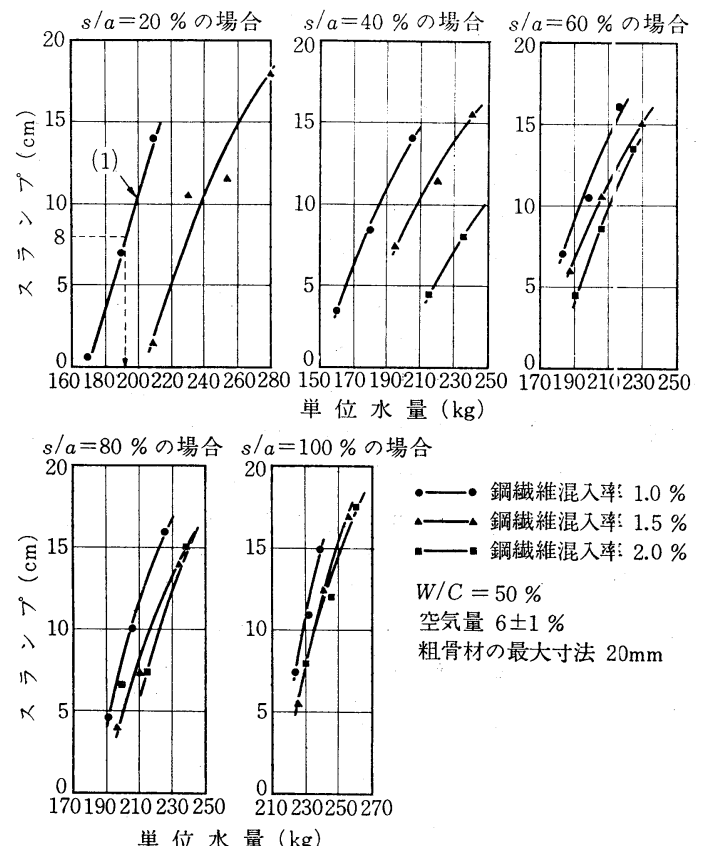

- —— 鋼繊維混入率! $1.0 \%$ ——鋼瀻維混入率: $1.5 \%$ ——鋼繊維混入率: $2.0 \%$ $W / C=50 \%$ 空気量 $6 \pm 1 \%$ 粗骨材の最大寸法 $20 \mathrm{~mm}$

\section{図一5 単位水量とスランプの関係}




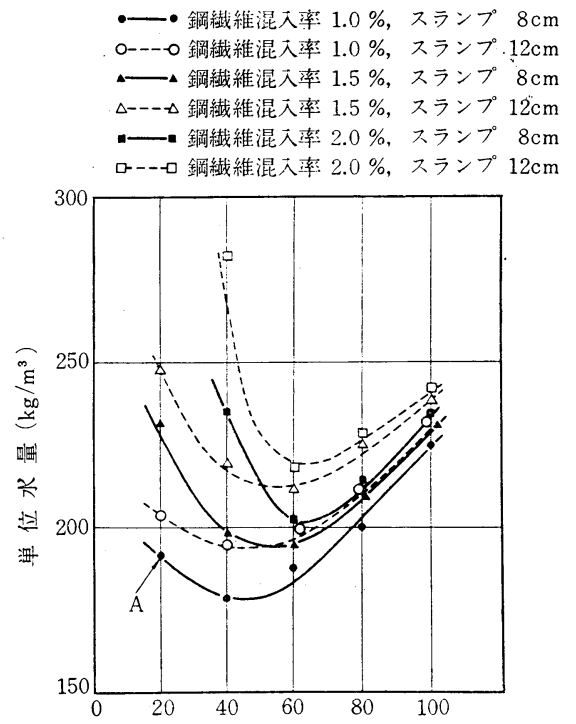

[条件]

細骨材率（\%)

セメント：普通ポルトランドセメント 細骨材: 粗粒率 3.15 の川砂 粗骨材: 最大寸法 $20 \mathrm{~mm}$ 砕石鋼緎維: $0.5 \times 0.5 \times 30 \mathrm{~mm}$ 水セメント比：50\% 空気量： $6 \pm 1 \%$

\section{図一6 スランプー定の時の細骨材率と単位水量の関係}

ただし，実際の施工においては計量誤差などのために細 骨材率が所定值よりずれる場合, 細骨材率が小さい方へ ずれるよりも大きい方へずれる方が取扱い上容易である ことは経験的に知られている。これは, 細骨材率が小さ くなるとコンクリートが荒々しくなり材料分離の傾向を 示すためである。従って, 配合設計に当っては, 単位水 量が最小になる細骨材率より幾分大きい細骨材率を選ぶ のがよいことになる。鋼繊維混入率が同じ場合，スラン プが大きくなれば当然単位水量も大きくなるが，単位水 量が最小となる細骨材率はほとんど変わらないので, こ の関係から比例配分によって，任意のスランプに対する 単位水量の目安をつけることができる。

\section{（4）強度に及ぼす細骨材率の影響}

図一7 及び図一8 は, 鋼繊維補強 $\mathrm{AE}$ コンクリート の圧縮強度及び曲げ強度に及ぼす細骨材率の影響を検討 するために描いたものである。図中の各点は, 同一配合 のコンクリートの 2 個の供試体の平均值を示す。また,

各細骨材率の線上に同一の鋼繊維混入率の点が 3 個また は4 個散らばっているが，これらは単位水量の異なる配 合のものである。今回の実験では, 単位水量またはスラ ンプを一定とした実験を行わなかったので，これらの影 響を除くことはできないが，およその傾向をみることは できる。すなおち，水セメント比が $50 \%$ で, 鋼繊維混 入率が 1.0 2.0\% の $\mathrm{AE}$ コンクリートの圧縮強度は, 図一7 に示すように, $300 \sim 400 \mathrm{~kg} / \mathrm{cm}^{2}$ 程度に分布して いるが，細骨材率が 40〜80\% の場合にくらべて，細骨 Vol. 16, No. 10, Oct. 1978

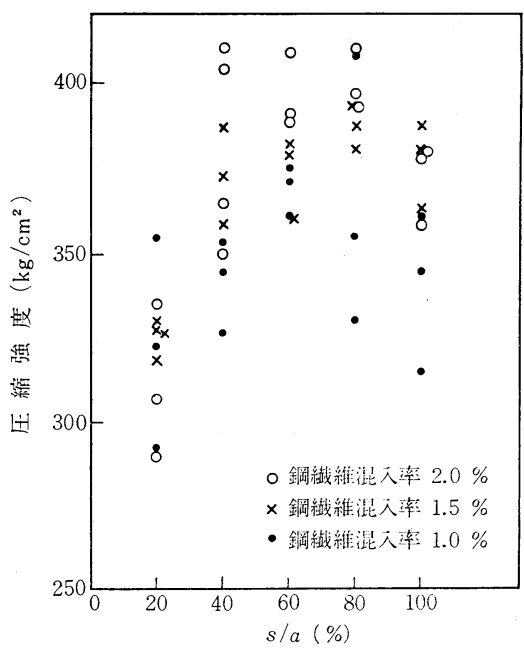

図一7圧縮強度と細骨材率との関係

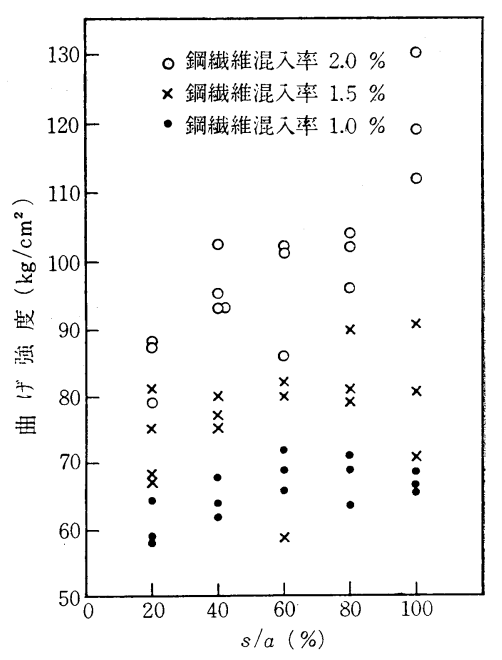

図一8曲け強度と細骨材率との関係

材率が極端に小さい場合 (20\%) 及び大きい場合 (100 \%)には，圧縮強度がやや低下する傾向がみられる。一 方, 曲げ強度は, 図一8 に示すように $60 \sim 130 \mathrm{~kg} / \mathrm{cm}^{2}$ 程度の範囲に分布しているが，細骨材率が 40 80\% の 範囲では鋼繊維混入率に応じてほぼ一定の值を示してい る。

前節では，スランプ一定の条件で単位水量を最小にす る細骨材率に注目し，さらに経験的判断を加えて配合設 計に用いる細骨材率を求めることを述べたが，そのよう にして求めた細骨材率は, 強度に及ぼす細骨材率の影響 を考慮しても妥当な值であると考えられる。

5.まとめ

市販の鋼繊維 1 種を用いて, 鋼繊維補強 $\mathrm{AE}$ コンク 
リートの配合試験を行った結果，つぎのようなことが明 らかになった。

1） $\mathrm{AE}$ 剤を用いないコンクリートでは, 鋼繊維混入 の有無にかかわらず, スランプの増大に伴って空気量が 滅少する傾向が認められる。一方，セメント量に対する $\mathrm{AE}$ 剤の重量比を一定にした $\mathrm{AE}$ コンクリートでは, 鋼 纎維混入の有無によって空気量に及ぼすスランプの影響 は異なった傾向を示す。すなわち，鋼瀻維を混入しない $\mathrm{AE}$ コンクリートでは, スランプの増大によって空気量 が減少するのに対し, 鋼繊維補強 $\mathrm{AE}$ コンクリートで は, スランプの増大に伴って空気量も増大する。

鋼繊維の混入による空気量の変化々鋼繊維補強 $\mathrm{AE}$ 二 ンクリートのスランプとの関係は，お㧤む数線的であ ると認められる。

2) 鋼纎維補強 $\mathrm{AE}$ コンクリートでは, 鋼繊維を混 入しない $\mathrm{AE}$ コンクリートに比べて，スランプに及ぼ す空気量の影響が小さいと認められる。

3) 細骨材率の小さい配合では, 鋼繊維補強 $\mathrm{AE}$ ב ンクリートのスランプが大きくなると鋼繊維の混入によ るスランプの減少が小さくなる傾向が認められるが，細 骨材率の大きな配合では，このような傾向はなく不規則 に変化している。

4） スランプ一定の条件に扔ける鋼繊維補強 $\mathrm{AE}$ ב ンクリートの細骨材率と単位水量との関係をみると, 単 位水量を最小とする細骨材率が存在する。一方, 鋼繊維
補強 $\mathrm{AE}$ コンクリートの強度と細骨材率との閔係から は, 細骨材率は 40〜80\% の範囲 (ただし, 粗督材の最 大寸法 $20 \mathrm{~mm}$ の場合) が妥当とみられ, 単位水量が最 小之なる細骨材率屺この範囲内にある。従って, 鋼纎維 補強 $\mathrm{AE}$ コンクリートの配合は, 所要のスランプが得 られ, かつ単位水量を最小とする細骨材率に注目し, こ れ汇経験的判断を加えて定めるのが良いと考えりれる。

\section{6.おわりに}

限られた条件下での実験結果ではあるが，鋼結維補強 $\mathrm{AE}$ コンクリートの配合に関する若干の知識を得ること ができた。この資料が鋼繊維補強コンクリートの配合設 計に役立てば幸である。

なお, この実験の計画に際しては, 東京大学の小林一 輔教授に御指導をいただいた。ここに付記して感謝の意 を表します。

\section{参 考 文 献}

1）宮坂慶男: 図解コンクリートの施工実務, 山海学:, 1972 年 10 月

2) 小林一輔：鋼繊維補強コンクリートの配合，コンクリー 卜工学, 1977 年 3 月

3) 小林一輔, 伊藤利治, 星野富夫 : 鋼繊維補強コ:ンクリー 卜の諸性状々繊維の形状特性, 生産研究, 1974 年 12 月

4) 小林一輔, 岡村雄樹 : 鋼䋊維補強コンクリートの, コンシ ステンシーに関する実験, 生産研究, 1976 年 2 F

（投稿：昭和 53 年 2 月 25 日疍付）

\section{- $<$ 図 書 案 内 $>$

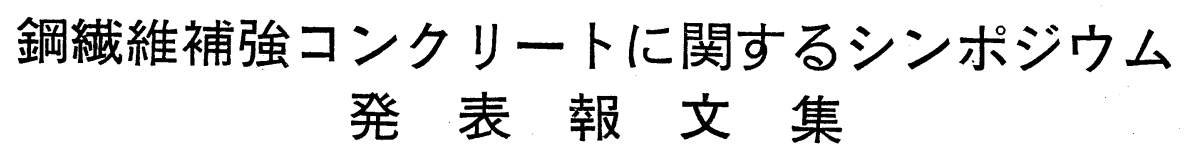

B 5 判 176 頁 定価 1500 円（会員特価 1200 円）送料 300 円

口特別講演＝鋼繊維補強コンクリートの活用分野（伊吹山四郎）

$\S 1$ 強化機構・強度

$\S 2$ 繊維の性質・一般的特性

$\S 3$ 部材の挙動

$\S 4$ 配合設計・施工

$\S 5$ 試験施工例・吹付工法

-申込先 : 社団法人 日本コンクリート工学協会

102 東京都千代田区趜町 5 丁目 7 番地 秀和紀尾井町 TBR 708 